\title{
PERAN PERAWAT DALAM MELAKSANAKAN PERENCANAAN ASUHAN KEPERAWATAN PADA PASIEN DIARE
}

\author{
Muhaini Atmayana Purba / 181101131
}

muhainipurba21@gmail.com

\begin{abstract}
ABSTRAK
Latar belakang : Diare merupakan penyebab kematian nomer dua di dunia. Salah satu target MDGs adalah menurunkan angka kematian pada anak, termasuk menurunkan angka kematian yang diakibatkan diare. Tujuan : Tujuan penulisan ini yaitu mengidenifikasi peran perawat dalam melaksanakan perencanaan asuhan keperawatan pada pasien diare. Metode : Metode yang digunakan merupakan literatur review atau suatu perbandingan atau analisis antara satu jurnal dengan jurnal lainnya dari berbagai sumber seperti referensi jurnal, buku teks dan e-book. Hasil : Ada kekuatan dan kelemahan untuk manajemen diare dari perawat. Kekuatan yaitu Perawat melakukan penilaian umum diare dan dehidrasi, Perawat melakukan perumusan diagnosis keperawatan, intervensi, implementasi dan evaluasi, kolaborasi perawat dengan tim kesehatan lainnya, seperti dokter, pekerja laboratorium, Perawat memberikan pendidikan dalam penyediaan rehidrasi oral, seng, makan dan pendidikan dan Perawat melakukan peran sebagai pelindung: konsentrat informasi. Kelemahannya yaitu dokumentasi Perawat terkandung dalam formulir asuhan keperawatan terpisah, Tidak ada pemeriksaan dehidrasi berat, Anak selalu mendapat tambahan cairan parenteral, Nuse masih memberikan antibiotik untuk anak-anak dengan diare akut, Anak diberi prebiotik, Perawat tidak memberikan penjelasan kepada orang tua tentang durasi seng dan Perawat melakukan konsentrasi informasi tetapi belum didokumentasikan. Kesimpulan : Perawat telah bekerja pada peran dalam manajemen diare akut untuk anak-anak, di mana peran ini ada kekuatan dan kelemahan pelaksanaan peran tersebut.
\end{abstract}

Kata Kunci : Peran perawat, asuhan keperawatan, pasien diare.

\begin{abstract}
Background : Diarrhea is the number two cause of death in the world. One of the MDG targets is reducing mortality in children, including reducing mortality due to diarrhea. Purpose : The purpose of this paper is to identify the role of nurses in implementing nursing care planning in diarrhea patients. Method : The method used is a literature review or a comparison or analysis of one journal with other journals from various sources such as journal references, textbooks and e-books. Results : There are strengths and weaknesses for the management of diarrhea from nurses. Strengths: Nurses carry out general assessment of diarrhea and dehydration, nurses carry out formulations of nursing diagnoses, interventions, implementations and evaluations, nurses collaborate with other health teams, such as doctors, laboratory workers, nurses provide education in the provision of oral rehydration, zinc, food and education and nurses perform the protective role: the information concentrate. Weaknesses are the nurse's documentation contained in a separate nursing care form, there is no severe dehydration check, the child always gets extra parenteral fluid, Nuse still gives antibiotics to children with acute diarrhea, the child is given prebiotics, the nurse does not give an explanation to parents about the duration of zinc and The nurse concentrates information but has not been documented. Conclusion : Nurses have worked on roles in the management of acute diarrhea for children, where this role has strengths and weaknesses in the implementation of that role.
\end{abstract}

Keywords : Role of nurses, nursing care, diarrhea patients. 


\section{Latar Belakang}

Diare merupakan penyebab kematian nomer dua di dunia (WHO, 2013). Salah satu target MDGs adalah menurunkan angka kematian pada anak, termasuk menurunkan angka kematian yang diakibatkan diare. Jika upaya dalam menangani masalah diare tidak dilakukan dengan cepat dan berkelanjutan, maka dimungkinkan sebanyak 760.000 anak akan meninggal oleh karena diare setiap tahunnya. Tetapi jika penanganan diare dilakukan dengan cepat dan tepat, maka jumlah kematian anak karena diare akan menurun setiap tahunnya (WHO, UNICEF, 2013).

Upaya untuk menurunkan angka kematian anak karena diare dengan melakukan tatalaksana secara tepat dan akurat. WHO mengembangkan kerangka kerja pelayanan kesehatan yang salah satunya dalam buku pelayanan kesehatan anak di rumah sakit, di dalamnya berisi panduan tatalaksana anak sakit di rumah sakit oleh tenaga kesehatan termasuk perawat, dengan lima langkah tuntaskan diare (lintas) diare (WHO, 2008). Dalam tatalaksana diare, perawat dapat melaksanakan perannya dalam beberapa hal, salah satunya adalah memberikan pendidikan kepada orang tua mengenai rehidrasi oral untuk mengatasi diare. Seperti penelitian di India yang dilakukan oleh Mazumder et al (2010), dikemukakan bahwa pendidikan yang diberikan kepada orang tua atau pengasuh mengenai pemberian zink dan oralit untuk anak diare, efektif dapat mengurangi diare pada anak. Penelitian di Indonesia tentang tatalaksana diare yang sudah dilakukan di 18 rumah sakit, untuk mengetahui gambaran perawatan pada anak di rumah sakit, diperoleh hasil bahwa kelemahan yang didapatkan dari skor diare adalah adanya rencana rehidrasi yang tidak jelas, diberikannya cairan intravena pada semua kasus diare sedangkan oralit tidak diberikan, dan masih diberikannya antibiotik dan antidiare untuk diare cair (Sidik et al, 2013).

Dari survei pendahuluan terdapat beberapa permasalahan terkait tatalaksana diare, diantaranya adalah belum ada bukti Standar Pelayanan Medis (SPM) untuk diare, antibiotik masih diberikan pada anak diare akut dan perawat belum menjalankan peran sebagai pelindung, untuk melindungi pasien dari pemberian terapi. Kemudian pemberian tablet zink belum sesuai dengan dosis sesuai umur, perawat 
belum memberikan nasehat untuk orang tua mengenai kapan harus membawa anak kembali ke petugas, dan orang tua belum mengetahui dosis pemberian zink serta cara pemberian jika anak muntah, hal itu menunjukan bahwa perawat belum melaksanakan peran pendidik. Dari hal tersebut dirumuskan masalah apa peran perawat dalam tatalaksana diare akut dan bagaimana perawat melakukan tatalaksana diare akut.

\section{Tujuan}

Tujuan penulisan ini yaitu mengidenifikasi peran perawat dalam melaksanakan perencanaan asuhan keperawatan pada pasien diare.

\section{Metode}

Metode yang digunakan merupakan literatur review atau suatu perbandingan atau analisis antara satu jurnal dengan jurnal lainnya dari berbagai sumber seperti referensi jurnal, buku teks dan e-book.

\section{Hasil \& Pembahasan}

Dari hasil penelitian dokter tidak mengetahui secara pasti apakah perawat melakukan pengkajian atau tidak. Hal tersebut terjadi karena dokter berkunjung ke ruang anak hanya pada waktu pagi hari dan tidak melihat secara langsung pengkajian yang sudah dilakukan perawat. Selain itu, dokumentasi yang dilakukan perawat terdapat dalam form pengkajian keperawatan tersendiri, yang tidak menjadi satu dengan dokumentasi dokter, sehingga dokter tidak melihat dan mengetahui apa saja yang sudah dilakukan oleh perawat. Hal tersebut tidak sejalan dengan Komisi Akreditasi Rumah Sakit (KARS) pada standar pelayanan pasien (PP), yaitu pada standar PP 2.1 “Asuhan kepada pasien direncanakan dan tertulis di rekam medis pasien". Pada PP 2.1 menyebutkan bahwa dalam memberikan asuhan kepada pasien, sebaiknya dituangkan dalam satu rencana tunggal dan terintegrasi oleh masing-masing praktisi kesehatan. Hal yang serupa juga disampaikan oleh Joint Commission International (JCI, 2013), pada standar Care of Patient (COP), yang menjelaskan bahwa dalam pendokumentasian atau pencatatan, seharusnya terintegrasi atau seragam, untuk semua profesi, baik perawat ataupun dokter, mulai data subjektif dan objektif dari pengkajian, diagnosis, perecanaan, implementasi dan evaluasi. Apabila dokumentasi sudah seragam atau terintegrasi, maka dokumentasi yang tertulis bisa dibaca dan diketahui oleh profesi lain. 
Hasil penelitian menunjukan bahwa dari hasil kolaborasi dengan dokter, anak selalu mendapatkan tambahan cairan parenteral pada semua derajad dehidrasi. Hal itu tidak sesuai dengan diare Depkes (2011), yang memberikan panduan bahwa dalam memberikan cairan tambahan disesuaikan dengan derajad dehidrasi. Dengan tidak diberikannya cairan intravena, maka akan mengurangi resiko infeksi sekunder pada anak dan memungkinkan biaya perawatan anak yang lebih rendah (Depkes, 2011). Perawat dalam memberikan cairan intravena atas instruksi dokter. Sebagai perawat yang mempunyai fungsi dependent, semua tindakan yang dilakukan perawat berdasarkan instruksi dokter atau di bawah pengawasan dokter (Kozier, 2008). Menurut Pabundu (2008), salah satu faktor eksternal yang mempengaruhi kinerja adalah kebijakan. Perawat memberikan cairan intravena pada semua derajad dehidrasi karena adanya kebijakan dan instruksi dari dokter untuk memberikan cairan intravena.

Pemberian cairan intravena pada semua pasien diare di atas, tidak sesuai dengan KARS pada standar Pencegahan dan Pengendalian Infeksi
(PPI 6) dan JCI (2013), pada standar Prevention and Control of Infections (PCI 6), tentang "mengurangi resiko infeksi terkait dengan pelayanan kesehatan".

Pada peran perawat sebagai pendidik, perawat memberikan edukasi mengenai lama pemberian zink, yaitu 10 hari, tetapi pernyataan tersebut tidak didukung oleh data dari observasi, dokumentasi dan triangulasi dengan orang tua. Dari hal tersebut dapat diketahui, bahwa pengetahuan perawat mengenai lama pemberian zink sudah benar, tetapi belum diikuti dengan pemberian edukasi kepada orang tua mengani lama pemberian zink kepada anak dan belum dilakukan dokumentasi mengenai edukasi tersebut. Kenyataan yang terjadi belum sejalan dengan Depkes (2011), yang menyebutkan bahwa sebagai tenaga kesehatan, perawat hendaknya memberikan edukasi dan penekanan kepada orang tua mengenai dosis penuh zink yang harus diberikan kepada anak, yaitu selama 10 hari. Hal tersebut menunjukan bahwa perawat sudah menerapkan perawatan berpusat pada keluarga dan berprinsip pada atraumatic care dengan memberikan edukasi atau pemberian 
Perawat sudah melakukan informed consent, tetapi belum diikuti dengan pendokumentasian mengenai tindakan yang sudah dilakukan. Dari hal tersebut, perawat belum melaksanakan tanggung jawab dan tanggung gugat dalam upaya melindungi klien terhadap pelayanan atau tindakan yang didapatkan, karena dokumentasi merupakan bentuk pertanggungjawaban perawat terhadap tindakan yang sudah dilakukan (Handayaningsih, 2009). Tidak adanya dokumentasi membuat lemah suatu informed concent, karena dokumentasi diperlukan sebagai bukti jika terjadi suatu masalah yang berhubungan dengan profesi keperawatan.

\section{Kesimpulan \& Saran}

Perawat sudah melakukan manajemen diare akut pada anak, yang di dalamnya mengandung kekuatan dan kelemahan dari manajemen diare yang sudah dilakukan perawat tersebut.

\section{Daftar Pustaka}

Asmadi. 2008. Konsep Dasar Keperawatan. EGC. Jakarta

Dahlan, M. (2004). Statistik Untuk Kedokteran dan Kesehatan. Jakarta: Salemba Medika

Delaune dan Ladner. 2011. Fundamental of Nursing Standard and Practice. fourth Edition. Cengage Learning. Delmar.

Hafizurrachman, Trisnantoro, T, Bachtiar A. 2011. Beberapa Faktor yang Memengaruhi Kinerja Perawat dalam Menjalankan Kebijakan Keperawatan di Rumah Sakit Umum Daerah. J Indon Med Assoc 61 (10): 387-393.

Handayaningsih. 2009. Dokumentasi Keperawatan "DAR" Panduan, Konsep dan Aplikasi. Mitra Cendekia. Jogjakarta

Hockenberry, M.J., Wilson, D. 2011. Wong's Book 2 Nursing Care of Infants and Children. Edition 9. Mosby Elseiver. USA.

Ilyas, Y. (2012). Kinerja: Teori, penilaian, dan penelitian (Edisi revisi). Depok: Fakultas Kesehatan Masyarakat UI.

Jansen dan Stauffacher. 2010. Advanced Practice Nursing Core Concepts for Proffessional Role Development. Fourth edition. Springer Publishing Company. New York.

Joint Commission International (2013). Joint Commission International Acredditation Standards for Hospitals. 5th edition. JCI. USA 
Kementrian Kesehatan RI. 2011. Situasi

Diare di Indonesia. Triwulan II.

Kemenkes RI. Jakarta.

Keputusan Menteri Kesehatan Republik

Indonesia Nomor 1239 Tahun

2001 Registrasi dan Praktik

Perawat. 22 November 2001.

Menteri Kesehatan Republik

Indonesia. Jakarta.

Kozier, B. (2008). Fundamental Of

Nursing ; Concept, Process and

Practice. Addison Wesley Nursing

Cuming Publishing. New York.

Kusnanto. 2004. Pengantar Profesi dan

Praktik Keperawatan Profesional.

EGC. Jakarta.

Simamora, R. H. (2008). Peran Manajer

Perawat Dalam Pembinaan Etika

Perawat Pelaksana Dalam

Peningkatan Kualitas Asuhan

Keperawatan. IKESMA

Simamora, R. H. (2009). Dokumentasi

Proses Keperawatan. Jember.

University Press

Simamora, R. H. (2010). Komunikasi

Dalam Keperawatan. Jember:

University Press

Potter dan Perry. 2005. Fundamental

Keperawatan Konsep Proses dan

Praktik. Edisi 4. EGC. Jakarta.

PPNI. 2005. Standar Praktik

Keperawatan Indonesia. http://www.inna-

ppni.or.id/index.php/standar-

praktek. diunduh 03 September 2014.

WHO (2014). Intregated Management of Childhood Illness (IMCI). Distance Learning Course, Modul 4 Diarrhoea. WHO. Switzerland

WGO. 2008. World Gastroenterology Organisation practice guideline: Acute diarrhea. WGO.

WHO. 2005. The Treatment of Diarrhoea, A manual for physicians and other senior health workers. 4th rev. WHO. Geneva.

WHO, UNICEF. (2013). Ending Preventable Child Deaths from Pneumonia and Diarrhoea by 2025 The integrated Global Action Plan for Pneumonia and Diarrhoea (GAPPD). WHO. France.

Widayanti, E. (2013). Evaluasi Kerasionalan Pengobatan Diare (non Spesifik) Di Puskesmas Kabupaten Sleman Tahun 2011. Tesis. Fakultas Kedokteran Universitas Gadjah Mada. Yogyakarta. 